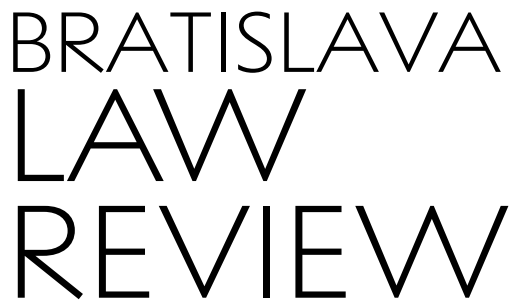

PUBLISHED BY

THE FACULTY OF LAW, COMENIUS UNIVERSITY IN BRATISLAVA

\title{
INTERNATIONAL AND NATIONAL LEGAL ASPECTS OF DIRECT CITIZEN PARTICIPATION IN LOCAL SELF-GOVERNMENT (BRATISLAVA, 3 DECEMBER 2020) / L'udovít Máčaj
}

\author{
Mgr. L'udovít Máčaj, PhD. \\ Comenius University in Bratislava, \\ Faculty of Law, Department of \\ Administrative and Environmental \\ Law; Šafárikovo nám. 6; 81800 \\ Bratislava, \\ ludovit.macaj@uniba.sk
}

This report was prepared as part of the research project $V E G A$ No. 1/0757/20 titled "Means of direct democracy in the conditions of smart cities and municipalities"

Submitted: 11 December 2020 Published: 31 December 2020

\section{Suggested citation:}

Máčaj, Ĺ. (2020). International and National Legal Aspects of Direct Citizen Participation in Local Self-Government (Bratislava, 03 December 2020). Bratislava Law Review, 4(2), 201-204. https://doi.org/10.46282/blr.2020.4.2.217

On the 3rd December 2020, Comenius University in Bratislava, Faculty of Law organized an international scientific conference entitled "International and national legal aspects of direct citizen participation in local self-government". It was organized online via the MS Teams application. The conference represented the outcome of the research team concerning the project VEGA No. 1/0757/20 titled "Means of direct democracy in the conditions of smart cities and municipalities", awarded by the Scientific Grant Agency of the Ministry of Education, Science, Research and Sport of the Slovak Republic and the Slovak Academy of Sciences.

The aim of the conference was to identify shortcomings of the legal regulation of the means of direct democracy at the level of local self-government and the possibilities of their implementation electronically in Slovakia, as well as the advantages of foreign legal regulation. Its ambition was to join the voices drawing attention to the need for wider digitization of public administration with a special focus on the implementation of direct forms of local democracy in Slovakia.

The conference was held under the auspices of doc. JUDr. Livia Trellová, PhD. from Comenius University in Bratislava, Faculty of Law. She opened the conference with a speech and also welcomed all guests. At the same time, she presented the tasks and goals of the project, not only about this calendar year but also other next years of the project duration. 
A total of 20 participants registered for the conference, while 11 separate scientific submissions were presented during the meeting. The conference was attended by representatives of the academic community from Comenius University in Bratislava, Faculty of Law, and also guests from Slovakia and the Czech Republic, as well as representatives of legal practice and the third sector (their workplace is mentioned below).

The introductory lecture was given by doc. JUDr. Marek Domin, PhD., who outlined the constitutional basis of direct democracy at the municipal level and tried to answer whether the current legal regulation of local referendum in Slovakia contains a sufficient guarantee of the implementation of the constitutional principles. Then the word was given to prof. JUDr. Mária Srebalová, PhD., who presented a submission about good governance in local self-government communication, which was prepared with the doc. PhDr. JUDr. Tomáš Peráček, PhD. from Department of Information System of Faculty of Management, Comenius University in Bratislava. In their contribution, they pointed out the possibilities on the basis of which the means of direct democracy could be put into practice, using several means of practical research to obtain information. In the third presentation, Ing. Paul Pirovits, as a representative of the third sector (civic associations "Priama demokracia" and "Robme to správne") focused on the project of civil councils. He pointed to this project, in which the direct participation of citizens in the administration of public affairs is applied in a special way. He also addressed a call for the implementation of this project. The fourth contribution was presented by Mgr. Mária Bezáková. She pointed out the importance of the principle of direct democracy as one of the pillars of a democratic and rule of law and its importance in legislation.

The second session of the conference focused on aspects of issues of spatial planning, administrative law as well as application practice. It was opened by Mgr. L'udovít Máčaj, PhD., pointing out issues of the possibilities of direct participation of the population of the municipality in spatial planning, with the perspective of landscape planning as an institute of nature and landscape protection. JUDr. Štefan Haulík focused on certain issues of present tools of direct democracy on the level of municipalities. Even if these tools are guaranteed and protected by the highest level of the legal order, for instance by the Constitution of the Slovak Republic, they are not sufficiently used in legal practice. JUDr. Matúš Radosa analyzed the electronic performance of direct participation of the population in local self-government in the light of the current legal regulation of the European Union. The session continued with the submissions of two Czech guests. JUDr. Ing. Josef Staša, CSc. from Charles University in Prague presented several considerations on the participation of citizens in spatial planning at the municipal level while presenting some interesting reflections on the future possibilities of legislation in this area. JUDr. Monika Horáková, Ph.D. from Palacký University in Olomouc presented her ideas about local referendum on territorial changes of the municipality.

The final session was opened by Mgr. Lukáš Tomaš from Pavol Jozef Šafárik University in Košice, with the analysis of the decision-making practice of the Supreme Administrative Court of the Czech Republic in matters of construction of local referendum issues and possibilities of its evaluation in the conditions of Slovakia. Subsequently, Mgr. Ján Mazúr, PhD. presented his submission on the alternative tools for involving the population in local self-governance. He described the Slovak application Link for Mayor (OPS), as well as examples of similar deliberative applications that allow citizens to formulate their political preferences, making them instruments of direct democracy at the local level. Finally, doc. JUDr. Lívia Trellová, PhD. concluded the conference with her contribution and a summary of problematic issues in the field of direct democracy at the local level, which will be further explored and developed in the direction of proposing new legal solutions within the project. 
The conference brought an exchange of views between legal theory, legal practice, and the third sector. We believe that it provided a certain basis for the further solution of the mentioned project, which can be very important at present when more and more activities are being moved to the online space. At the same time, it provides more opportunities for the use of the means of direct democracy, the application of which is suitable at the level of local self-government. 
